\title{
Effect of Picloram on Somatic Embryogenesis from Leaf-sheath Explants in Diploid Musa acuminata cv. Njalipoovan
}

\author{
P.D. Smitha and Ashalatha S. Nair \\ Department of Botany, University of Kerala, Kariavattom, Thiruvananthapuram-695 581, \\ India
}

Key words: Musa acuminata cv. Njalipoovan, Picloram, Somatic embryogenesis

Embryogenic callus was obtained from leaf sheath explants on MS supplemented with $16.56 \mu \mathrm{M}$ picloram in Musa acuminata (diploid) cv. Njalipoovan (AB). Exogenous application of ascorbic acid on somatic embryogenesis at optimal level accelerated the conversion rate of the embryos. Shoot and root developed from the embryos on MS incubated in dark. Further growth of plantlets obtained on half strength of MS under light conditions. Regenerated plantlets showed $100 \%$ survival.

India has a rich genetic diversity of banana with more than 90 distinct clones. South India is well-known for the presence of numerous diploid as well as triploid edible banana cultivars (Heslop-Harrison and Schwarzacher 2007). Local or indigenous cultivars are generally more tolerant to local conditions and have lesser growth requirements to obtain satisfactory yield. Because of high sterility and polyploidy of the edible varieties (Stover and Simmonds 1987), conventional breeding is difficult in banana. The food value of bananas has been appreciated for a long time and continuous efforts are made to broaden the research on production of improved varieties. However, parthenocarpy, female sterility, polyploidy in different cultivars and limited amount of genetic and genomic information make the production of new banana cultivars difficult and time consuming. The alternative techniques such as tissue culture has been attempted in order to induce variations in banana plants and to select variants having desired qualities (Novak et al. 1989). Somatic embryogenesis was achieved using floral explants (Panis et al. 1993, Navarro et al. 1997) or cell suspensions of diploid and triploid cultivars with AA, AAA, AAB and ABB genomes (Cronauer and Krikorian 1983, Escalant and Teisson 1988, Ganapathi et al. 2001). Establishment of somatic embryogenesis has a great potential for overcoming some of the factors that limit traditional approaches to banana and plantain improvement. 
Njalipoovan is a popular shade-loving tolerant variety that has a great demand among consumers due to its superior fruit quality. The fruits of this variety are very sweet and soft with thin peel. It is less susceptible to most of the pests and diseases and adapted to rainfed cultivation with ratooning. The present study reports the production of embryogenic calli from the leaf sheath explants in Musa acuminata cv. Njalipoovan.

The rhizomes of sword suckers were collected and sterilized as per the methods developed by Vidhya and Nair (2002) for micropropagation. Three or four leaf sheaths surrounding the shoot meristems were collected from the sterilized rhizomes. The leaf sheath explants with basal meristem of $\sim 1 \mathrm{sq} \mathrm{cm}$ were isolated and inoculated on MS supplemented with 2,4-D (2.25 - $9 \mu \mathrm{M})$, and BA $(2.2-8.8 \mu \mathrm{M})$ or $\mathrm{Kn}(2.3-9.2 \mu \mathrm{M})$ and picloram $(0.414-16.56 \mu \mathrm{M})$ alone. The embryogenic calli were transferred to $150 \mathrm{ml}$ Erlenmeyer flask containing $20 \mathrm{ml}$ of liquid MS supplemented with ascorbic acid $(0.01-3.0 \mathrm{mg} / \mathrm{l})$. The cultures were incubated at $25^{\circ} \mathrm{C}, 50-70 \%$ relative humidity and $16 \mathrm{hrs}$ photoperiod with a light intensity of 3000 lux. The cultures were maintained through subculturing in the same medium at one month interval for a period of three months. Then callus with globular structures were transferred to the MS and incubated in the dark. The plantlets were separated and inoculated on half strength of MS. Regenerated plantlets were transplanted into paper cups containing vermiculite for two weeks. Hardened plantlets were transplanted to field.

Leaf sheath explants inoculated on MS supplemented with $2.25 \mu \mathrm{M}$ 2,4-D and $4.4 \mu \mathrm{M}$ BA initiated pale yellow compact callus within two weeks. After subculturing on the same medium, yellow globular structures developed from the callus. Brown compact callus with globular structures developed in a higher concentration of 2,4-D $(4.5-9.0 \mu \mathrm{M})$ with BA $(4.4-8.8 \mu \mathrm{M})$. The leaf sheath explants inoculated on MS supplemented with varying concentrations of 2,4-D and Kn showed development of brown spongy callus with globular structures (Table 1). Leaf sheath explants inoculated on MS supplemented with lower concentrations of picloram initiated brown spongy callus with yellow globular structures (Fig. 1). At higher concentrations of picloram, brown compact callus with white globular structures developed. These calli were subcultured in the same hormonal combinations for three months that led to increased development of globular structures (Fig. 2).

This was further subcultured on MS and incubated in dark conditions resulted shoot and root development (Fig. 3). The brown callus with white globular structures obtained from MS supplemented with $16.56 \mu \mathrm{M}$ picloram produced maximum number of somatic embryos that gave rise to plantlets on MS. The embryogenic calli subcultured on liquid MS supplemented with (0.01 $3.0 \mathrm{mg} / \mathrm{l}$ ) ascorbic acid enhanced somatic embryo conversion with concomitant 
reduction of blackening of the medium and callus. These plantlets were further developed on half strength of MS under light for four weeks. Then these plants were transferred to vermiculite. The hardened plantlets were transferred to pots with soil and cowdung $(1: 1)$ mixture in greenhouse conditions. The regenerated plants showed $100 \%$ survival rate.

Table 1. The effect of growth hormones on embryogenic callus induction in leaf sheath explants of Musa acuminata, sp. cv. Njalipoovan.

\begin{tabular}{llllll}
\hline $2,4-\mathrm{D}$ & $\begin{array}{l}\text { BA } \\
(\mu \mathrm{M})\end{array}$ & $\begin{array}{l}\text { Kn } \\
(\mu \mathrm{M})\end{array}$ & $\begin{array}{l}\text { Picloram } \\
(\mu \mathrm{M})\end{array}$ & $\begin{array}{l}\text { Morphology of } \\
\text { callus }\end{array}$ & $\begin{array}{l}\text { Frequency of embryo } \\
\text { in basal media }\end{array}$ \\
\hline 2.25 & 2.2 & - & - & PYC & - \\
2.25 & 4.4 & - & - & PYCG & - \\
2.25 & 8.8 & - & - & PYCG & - \\
4.5 & 2.2 & - & - & YCG & - \\
4.5 & 4.4 & - & - & BCG & - \\
4.5 & 8.8 & - & - & BCG & - \\
9 & 8.8 & - & - & BCG & - \\
& & & & & - \\
2.25 & - & 2.3 & - & BCG & - \\
2.25 & - & 4.6 & - & BCG & - \\
2.25 & - & 9.2 & - & BCG & - \\
4.5 & - & 2.3 & - & BCG & - \\
4.5 & - & 4.6 & - & BCG & - \\
4.5 & - & 9.2 & - & BSG & \\
9 & - & 9.2 & - & BSG & $3.6250 \mathrm{e}$ \\
& & & & & $3.5000 \mathrm{e}$ \\
- & - & - & 0.414 & BSYG & $4.2500 \mathrm{~d} \mathrm{e}$ \\
- & - & - & 1.242 & BSYG & $5.8750 \mathrm{~d} \mathrm{e}$ \\
- & - & - & 2.07 & BSYG & $7.000 \mathrm{~b}$ \\
- & - & - & 4.14 & BSYG & $9.2500 \mathrm{a}$ \\
- & - & - & 8.28 & BCWG & \\
- & - & - & 12.42 & BCWG & - \\
- & - & - & 16.56 & BCWG & - \\
\hline
\end{tabular}

PYC - pale yellow compact callus; PYCG - pale yellow compact callus with globular structures; YCG yellow compact callus with globular structures; BCG - brown compact callus with globular structures; BSG - brown spongy callus with yellow globular structures; BSYG - brown spongy callus with yellow globular structures; BCWG - brown compact callus with white globular structures.. Significance was determined by ANOVA: significant at $\mathrm{p}<0.01$.

Leaf sheath derived callus proliferation allowed for an exponential production of explants. This combined with satisfactory embryogenic frequencies facilitates the implementation of new approaches for the establishment of regenerable cell suspensions. Sadik et al. (2007) proposed initiation of cell suspension by scalp method reducing total time frequency for 
their establishment. Sidha et al. (2007) optimized in vitro culture condition for somatic embryogenesis in diverse Indian banana cultivars. However, in their study, Njalipoovan, Syn Safed Velchi (AB) did not show any response with any of the auxin due to genotypic variation. Banana cultivars exhibited differential response in terms of time taken for callus proliferation, embryo development, and embryo conversion to plants. Authors' study indicated that light also plays a crucial role in the development of embryos. Adapting this methodology to the use of leaf sheath derived embryogenic calli has been possible to complete the process of plant regeneration in diploid $\mathrm{AB}$ cultivars.
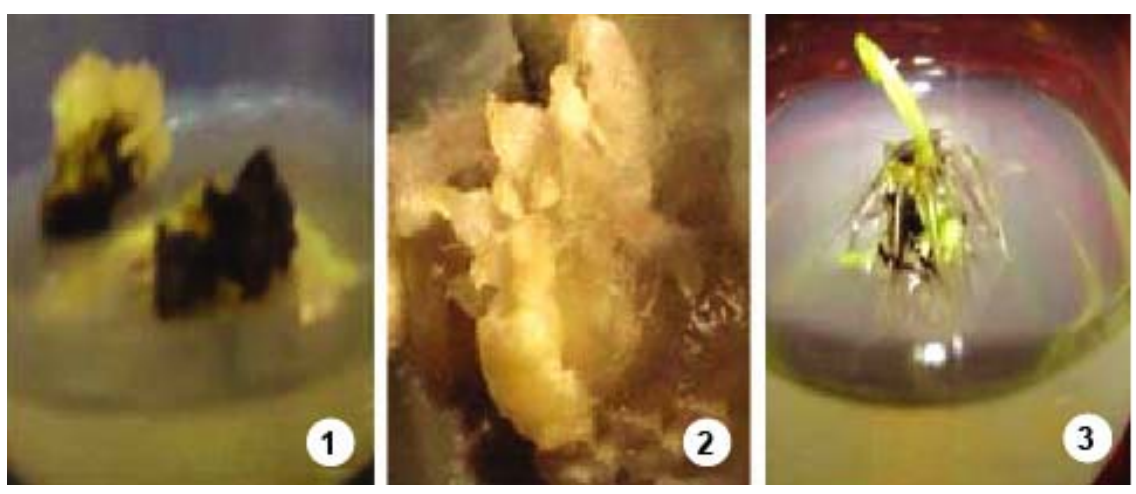

Figs 1-3: 1. Pale yellow spongy callus from the leaf explants inoculated on MS supplemented with $2.07 \mu \mathrm{M}$ picloram. 2. Development of globular structures. 3 . Development of shoot and roots from the somatic embryos on MS.

\section{References}

Cronauer S and Krikorian AD (1983) Somatic embryos from cultured tissues of triploid plantains (Musa ABB). Plant Cell Rep. 2: 289-291.

Escalant JV and Teisson C (1988) Embryogenese Somatique Chez Musa spp. Competes Rendus de Academic des Science. Paris Serie. III 306: 277-281.

Ganapathi TR, Srinivas L, Suprasanna P and Bapat A (2001) Regeneration of plants from alginate-encapusulated somatic embryos of banana cv. Rasthali (Musa spp. AAB group). In Vitro Cell Dev. Biol. Plant 37: 178-181.

Heslop-Harrison J and Schwarzacher T (2007) Domestication, genomics and the future for banana. Ann. Bot. 100: 1073-1084.

Navarao C, Escobedo RM and Mayo A (1997) In vitro plant regeneration from embryogenic cultures of a diploid and triploid Cavendish banana. Plant Cell Tiss. Org. Cult. 51: 17-25.

Novak FJ, Afza R, Van Duren, Perea M, Dallos B, Conger V and Xiaolang T (1989). Somatic embryogenesis and plant regeneration in suspension cultures of dessert (AA and AAA) and Cooking (ABB) bananas (Musa spp.) Bio/Technol. 7: 147-158. 
Panis BA, Wauwe V and Swennen R (1993) Plant regeneration through direct somatic embryogenesis from protoplasts of banana (Musa spp) Plant Cell Rep. 12: 403-407.

Sadik K, Rubaihayo PR, Magambo MJS and Pillay M (2007) Generation of Cell Suspensions of East African high land bananas through Scalps. African J. Biotech. 6: 1352-1357.

Sidha M, Suprasanna P, Bapat VA, Kulkarni UG and Shinde BN (2007) Developing somatic embryogenic culture system and plant generation in banana, BRAC Special Issue No. 285: 153-161.

Stover RH and Simmonds NW (1987). Bananas. Longman Scientific and Technical London.

Vidhya R and Nair AS (2002) Molecular analysis of somaclonal variations in Musa acuminata (AAA) Cv. Red. Phytomorphology 52(4): 293-300. 